\title{
COMPARATIVE EVALUATION OF REAL-TIME PCR WITH CONVENTIONAL PCR ASSAY FOR DIAGNOSIS OF BRUCELLOSIS IN RUMINANTS
}

\author{
M. Z. Saleem ${ }^{1 *}$, R. Akhtar 1 , A. Aslam ${ }^{1}$, M. I. Rashid ${ }^{2}$, Z. I. Chaudhry ${ }^{1}$, B. A. Shah $^{3}$, R. Ahmed ${ }^{4}$, M. Akmal ${ }^{5}$ and \\ G. Murtaza ${ }^{5}$ \\ ${ }^{1}$ Department of Pathology, ${ }^{2}$ Department of Parasitology, ${ }^{3}$ Department of Clinical Medicine, University of Veterinary and \\ Animal Sciences, Lahore, Pakistan; ${ }^{4}$ Department of Microbiology, Cholistan University of Veterinary and Animal \\ Sciences, Bahawalpur, Pakistan; ${ }^{5}$ Livestock Production Research Institute Bahadurnagar Okara, Livestock \& Dairy \\ Development Department, Pakistan. \\ "Corresponding author’s e-mail address: zain.saleem@uvas.edu.pk
}

\begin{abstract}
Brucellosis is zoonotic and highly infectious disease which not only causes the economic losses in ruminants but also infect the humans. In the present study, we compared the molecular techniques of PCR versions and clinical specimens for the diagnosis of brucellosis in ruminants. Blood and serum samples were collected from 692 cattle, 798 buffalo, 471 sheep and 960 goats from two areas; Kasur and Sheikhupura. After serological screening with Rose Bengal antigen, the seropositive serum samples of 73 cattle, 61 buffalo, 91 sheep and 118 goats were subjected to Real-time PCR and Conventional PCR for comparison. Real-time PCR detected significantly $(P \leq 0.01)$ more Brucella abortus (66 cattle, 53 buffalo) and Brucella melitensis (59 sheep, 81 goats) in large and small ruminants, respectively in the serum samples of seropositive ruminants than conventional PCR (45 cattle, 37 buffalo, 34 sheep and 47 goats). The Chi-square analysis confirmed significantly $(P \leq 0.01)$ more detection of B. abortus (66 cattle, 53 buffalo) and B. melitensis (59 sheep, 81 goats) in serum samples specimens of cattle, buffalo and sheep, goats, respectively than their respective blood samples (48 cattle, 39 buffalo, 44 sheep and 63 goats) in seropositive ruminants. It can be concluded that real-time PCR assay is more sensitive and reliable method for the diagnosis of brucellosis, that serum is the optimal specimen for the diagnosis of brucellosis by Real-time PCR.
\end{abstract}

Key words: Brucellosis, B. abortus, B. melitensis, Buffalo, Cattle, PCR, RBPT, Molecular diagnosis.

https://doi.org/10.36899/JAPS.2020.6.0159

Published online August 03,2020

\section{INTRODUCTION}

Brucellosis is an important zoonotic disease affecting both large and small ruminants. Control and eradication of the disease is imperative from public health point of view. But from the last few years its prevalence in Pakistan is increasing day by day (Ali et al., 2015). In developed countries it has been eradicated but it is still present in developing and tropical countries (Pappas et al., 2006). To decrease the economic losses due to brucellosis, accurate, safe and more sensitive molecular diagnostic techniques play a significant role for the eradication and control of brucellosis in ruminants (Habtamu et al., 2013; Verma et al., 2014). There are several diagnostic tests available for brucellosis, including serological, culture and molecular based assays. Culture methods entail a living host and are both time consuming and hazardous for laboratory workers (Navarro et al., 2004). Diagnosis of brucellosis in small and large ruminants by serological techniques is not recommended (Nielsen et al., 2004). As it can lead to cross-reaction and are sub-sensitive and unspecific with other pathogens including Escherichia coli O: 157, Salmonella, Yersinia enterocolitica and other Brucella spp. (Cventik et al., 2004). The traditional method for the diagnosis of Brucella spp. is based on phenotypic characters, but it accompanies a high risk of laboratoryacquired contaminations and are time consuming (Navarro et al., 2004). Thus, in order to expedite these difficulties, and seeing the high degrees of genetic similarity of different species of Brucella, there are numerous molecular based diagnostic assays that are more convenient, faster, safer, easier and accurate such as PCR, real time PCR, LAMP, sequencing and others (Scott et al., 2007; Foster et al., 2008; Karthik et al., 2014b). Molecular based assays have been applied for the diagnosis of Brucella in a wide variety of clinical specimens as accurate and sensitive techniques (Karthik et al., 2014a). For other fastidious bacterial pathogens, molecular based techniques offers an alternative way of diagnosing brucellosis. Genomic based amplification techniques, such as PCR is a highly sensitive and specific assay that can eliminate the limitations of conventional techniques (Karthik et al., 2016). Limited studies have addressed direct detection of Brucella species in preferred clinical specimens of ruminants for diagnostic purposes (Khan and Zahoor, 2018). In present study, our aim was to compare a more sensitive diagnostic PCR 
assay and define the optimal clinical specimen for the diagnosis of brucellosis. For this purpose, peripheral blood samples from seropositive ruminants, i.e., whole blood and serum, were examined and tested by real-time PCR and conventional PCR to compare their utility as rapid and sensitive diagnostics for brucellosis in ruminants. So that appropriate adoptive measures could be taken for the control of brucellosis.

\section{MATERIALS AND METHODS}

Serum and blood samples were collected from small and large ruminants. After serological screening only blood and serum samples of seropositive animals were stored. DNA was extracted from these samples. In first part of experiment sensitivity of real-time PCR was compared with conventional PCR for the diagnosis of brucellosis from serum samples. While in second part of experiment serum samples were compared with blood samples for the diagnosis of brucellosis by most sensitive molecular technique; Real-time PCR.

Sampling: The blood samples were collected in both EDTA and without anticoagulant added BD Vacutainer ${ }^{\circledR}$ from 692 cattle, 798 buffalo, 471 sheep and 960 goats from two areas; Kasur (Latitude: $31.0896^{\circ} \mathrm{N}$, Longitude: $74.1240^{\circ}$ E) and Sheikhupura (Latitude: $31.6243^{\circ} \mathrm{N}$, Longitude: $74.1240^{\circ}$ E) because previously brucellosis has been reported from Sheikhupura and Lahore districts (Ahmed et al., 2017). The samples were collected from the animals having age between 2 to 8 years, no vaccination of brucellosis and history of abortion at farm. The serum was separated from non EDTA added vacutainers and stored. GIS (Geographic information system) mapping was developed by using $Q G I S^{\circledR}$ software 2.18.9 version (Quantum geographic information system) for recording the sampling areas.

Screening of samples: All the serum samples were screened by Rose-Bengal Plate Test (RBPT). Antigen was procured from Veterinary Research Institute (VRI), Lahore, Pakistan. Serum sample of $30 \mu \mathrm{L}$ was mixed and agitated for four minutes with an equal quantity of antigen on glass slide. Serum samples were considered positive after agglutination (Ali et al., 2015). After screening all serum and respective blood samples of seropositive animals were subjected to further molecular investigation.

DNA extraction: DNA was extracted from blood and serum samples of seropositive animals by using Exgene $^{\mathrm{TM}}$ SV-mini Kit (GeneALL $®$ Biotechnology Co. Ltd, Songpa-gu, Korea) according to manufacturer's instruction. The extracted genome concentration was tested by using Nano Drop. Genomic samples were stored at $-20{ }^{\circ} \mathrm{C}$. DNA samples were analyzed by species specific primers of $B$. abortus and $B$. melitensis for conventional PCR as given in Table 1. While for Realtime PCR the primers with probe which are used are given in Table 2 .

Table 1. Species specific primers for conventional PCR (Bricker and Halling 1994).

\begin{tabular}{|c|c|c|c|c|}
\hline Specie & Primers & Sequence (5' to 3') & Target & Product \\
\hline \multirow[t]{2}{*}{ B. abortus } & Forward & GACGAACGGAATTTTTCCAATCCC & IS711/alkB & $498 \mathrm{bp}$ \\
\hline & Reverse & TGCCGATCACTTAAGGGCCTTCAT & & \\
\hline \multirow[t]{2}{*}{ B. melitensis } & Forward & AAATCGCGTCCTTGCTGGTCTGA & IS711/alkB & $731 \mathrm{bp}$ \\
\hline & Reverse & TGCCGATCACTTAAGGGCCTTCAT & & \\
\hline
\end{tabular}

Table. 2. Species specific primers and probe for Real-time PCR (Probert et al., 2004).

\begin{tabular}{|c|c|c|c|c|}
\hline Specie & Primers/Probe & Sequence (5' to $\left.3^{\prime}\right)$ & Target & $\begin{array}{c}5 \text { Fluorophore/3 } \\
\text { quencher }\end{array}$ \\
\hline$B$. & Forward & GCGGCTTTTCTATCACGGTATTC & alkB & HEX/BHQ1 \\
\hline \multirow[t]{2}{*}{ abortus } & Reverse & CATGCGCTATGATCTGGTTACG & & \\
\hline & Probe & CGCTCATGCTCGCCAGACTTCAATG & & \\
\hline$B$. & Forward & AACAAGCGGCACCCCTAAAA & alkB & Texas Red/BHQ2 \\
\hline \multirow[t]{2}{*}{ melitensis } & Reverse & CATGCGCTATGATCTGGTTACG & & \\
\hline & Probe & CAGGAGTGTTTCGGCTCAGAATAATCCACA & & \\
\hline
\end{tabular}

Amplification by conventional PCR: GeneAmp ${ }^{\mathrm{TM}}$ PCR master mix (GeneALL® Biotechnology Co. Ltd, Songpagu, Korea) was used in master mix of reaction mixture. Reaction mixture of $20 \mu \mathrm{L}$ containing $10 \mu \mathrm{L}$ of master mix, $1 \mu \mathrm{L}$ each forward and reverse primers having 10 $\mathrm{pmol} / \mu \mathrm{L}, 2 \mu \mathrm{L}$ genome of interest and $6 \mu \mathrm{L}$ Nuclease- free water was subjected to PCR. DNA of Brucella reference strains (BA 544 and BM-16M) obtained from Veterinary Research Institute (VRI), Lahore, Pakistan was used as positive control. Nuclease-free water was used as negative control (NC). Amplification of reaction was done in 96 well microplate thermocycler (Thermo 
Fisher Scientific Inc., Agilent Technologies, Santa Clara USA) having cycling conditions as follows; initial decontamination at $50^{\circ} \mathrm{C}$ for 5 minutes then initial denaturation at $95^{\circ} \mathrm{C}$ for 10 minutes followed by 40 cycles each consisting denaturation at $95^{\circ} \mathrm{C}$ for 30 seconds and annealing at $60^{\circ} \mathrm{C}$ for 30 seconds followed by extension at $72^{\circ} \mathrm{C}$ for 1 minute. Final extension of amplification was done at $72^{\circ} \mathrm{C}$ for 5 minute.

Amplification by real-time PCR: Amplification of reaction mixture was performed by using prepared Real$\mathrm{Amp}^{\mathrm{TM}}$ TaqMan qPCR master mix (Cat\# 801-020, GeneALL ${ }^{\circledR}$ Biotechnology Co. Ltd, Songpa-gu, Korea). A reaction mixture of $20 \mu \mathrm{L}$ containing $10 \mu \mathrm{L}$ of master mix, $0.5 \mu \mathrm{L}(200 \mathrm{nmol})$ of each forward and reverse primers, $1 \mu \mathrm{L}(100 \mathrm{nmol})$ of probe, $1 \mu \mathrm{L}$ of DNA and $7 \mu \mathrm{L}$ of nuclease free water were used for amplification. The cycle threshold ( $\mathrm{Ct}$-value) below 40 was considered as positive. The PCR reaction was optimized for standard concentrations DNA, primers and probe. The known concentration of DNA standards were provided by VRI, Lahore. PCR conditions was followed and reaction mixture composition was prepared (Probert et al., 2004). Amplification of desired DNA was done in 72-well Rotor-Gene ${ }^{\circledR} \mathrm{Q}$ real-time PCR cycler (Qiagen Q-Rex Software 2.3.11.4.9-Windows platforms).Initial denaturation at $94^{\circ} \mathrm{C}$ for 10 minutes followed by 40 cycles of each consisting denaturation at $94^{\circ} \mathrm{C}$ for $30 \mathrm{sec}$, annealing at $60^{\circ} \mathrm{C}$ for $30 \mathrm{sec}$ and extension at $72^{\circ} \mathrm{C}$ for 30 sec. Final extension was done at $72^{\circ} \mathrm{C}$ for 7 minutes. Double stranded PCR product was detected by fluorescent dye associated with Probe at each extension step. An amplification curve of PCR product was analyzed and recorded through computerized software. Holding temperature was $4^{\circ} \mathrm{C}$ till further testing.

Statistical analysis: Standard error sample proportion was calculated by using $\mathrm{SE}_{\mathrm{P}}$ formula as given $S P e=$ $\sqrt{ }(P(1-P) / n)$ and statistical analysis using chi square by using SPSS for Windows version 20, SPSS Inc., Chicago, IL, USA (Statistical Package for Social Science). $P \leq 0.01$ was considered as significant.

\section{RESULTS}

Blood samples and serum samples were collected from cattle, buffalo, sheep and goats. All serum samples were subjected to serological screening for brucellosis by Rose Bengal antigen. The precipitation reaction confirmed the seropositive animals. Through serological screening we found out the seroprevalences of $10.54 \% \pm 0.0116,7.644 \% \pm 0.0093,19.32 \% \pm 0.289$ and $12.29 \% \pm 0.0105$ in cattle, buffalo, sheep and goats, respectively. In first part of experiment only these seropositive samples were subjected to real-time PCR and conventional PCR for assessing the comparative efficacy of these molecular techniques.

Real-time PCR detected significantly $(P \leq 0.01)$ more $B$. abortus in cattle and buffalo. Real-time PCR detected $90 \% \pm 0.039$ and $86 \% \pm 0.044$ B. abortus than conventional PCR that detected $61 \% \pm 0.057$ and $60 \% \pm 0.062$ in seropositive cattle and buffalo, respectively. Significantly $(P \leq 0.01)$ more $B$. melitensis were detected in sheep and goats by real-time PCR. $B$. melitensis was detected $64 \% \pm 0.050$ and $68 \% \pm 0.042$ by real-time PCR as compare to conventional PCR that detected $37 \% \pm 0.050$ and $39 \% \pm 0.044$ in seropositive sheep and goats respectively. The above mentioned results confirmed that real-time PCR is more sensitive than conventional PCR. These results are shown in table 3. Conventional PCR results of B. abortus are shown in figure 1 while overall amplification of real-time PCR is shown in figure 2.

Table 3. Comparison of real-time PCR with conventional PCR for the detection of brucellosis in ruminants.

\begin{tabular}{llcccc}
\hline \multirow{2}{*}{ Brucella species } & \multirow{2}{*}{ Animals } & \multicolumn{2}{c}{ Results } & \multicolumn{2}{c}{ Chi-square analysis } \\
\cline { 3 - 6 } & & Real-time PCR & Conventional PCR & Chi-square $\left(\chi^{2}\right)$ & $\boldsymbol{P} \leq \mathbf{0 . 0 1}$ \\
\hline B. abortus & Cattle & $66(90 \% \pm 0.039)$ & $45(61 \% \pm 0.057)$ & 16.573 & 0.000 \\
& Buffalo & $53(86 \% \pm 0.044)$ & $37(60 \% \pm 0.062)$ & 10.844 & 0.001 \\
B. melitensis & Sheep & $59(64 \% \pm 0.050)$ & $34(37 \% \pm 0.050)$ & 17.339 & 0.000 \\
& Goat & $81(68 \% \pm 0.042)$ & $47(39 \% \pm 0.044)$ & 19.735 & 0.000 \\
\hline
\end{tabular}

In second part of experiment serum and blood samples were compared by real-time PCR for the diagnosis of brucellosis in small and large ruminants. After serological screening the serum and respective blood samples of seropositive cattle, buffalo, sheep and goats were subjected to real-time PCR. Real-time PCR detected $90 \% \pm 0.035$ and $86 \% \pm 0.044$ B. abortus in serum samples than $65 \% \pm 0.055$ and $63 \% \pm 0061$ B. abortus in blood samples of seropositive cattle and buffalo respectively. Similarly real-time PCR detected $64 \% \pm 0.050$ and $68 \% \pm 0.042 B$. melitensis in serum samples than $48 \% \pm 0.052$ and $53 \% \pm 0.045$ B. melitensis in blood samples of seropositive cattle and buffalo respectively. Comparison through chi-square have confirmed the significantly $(\mathrm{P} \leq 0.01)$ more $B$. abortus and $B$. melitensis detection in serum samples of large and small ruminants respectively. The results of second part of experiment are presented in table. 
Table 4. Comparison of serum samples with blood for the detection brucellosis in ruminants through real-time PCR.

\begin{tabular}{llcccc}
\hline \multirow{2}{*}{ Brucella species } & Animals & \multicolumn{2}{c}{ Real-time PCR } & \multicolumn{2}{c}{ Chi -square analysis } \\
\cline { 3 - 6 } & & Serum & Blood & Chi-square $\left(\chi^{2}\right)$ & $\boldsymbol{P} \leq \boldsymbol{0 . 0 1}$ \\
\hline B. abortus & Cattle & $66(90 \% \pm 0.035)$ & $48(65 \% \pm 0.055)$ & 12.967 & 0.000 \\
& Buffalo & $53(86 \% \pm 0.044)$ & $39(63 \% \pm 0061)$ & 8.664 & 0.003 \\
B. melitensis & Sheep & $59(64 \% \pm 0.050)$ & $44(48 \% \pm 0.052)$ & 5.033 & 0.025 \\
& Goat & $81(68 \% \pm 0.042)$ & $63(53 \% \pm 0.045)$ & 5.772 & 0.016 \\
\hline
\end{tabular}

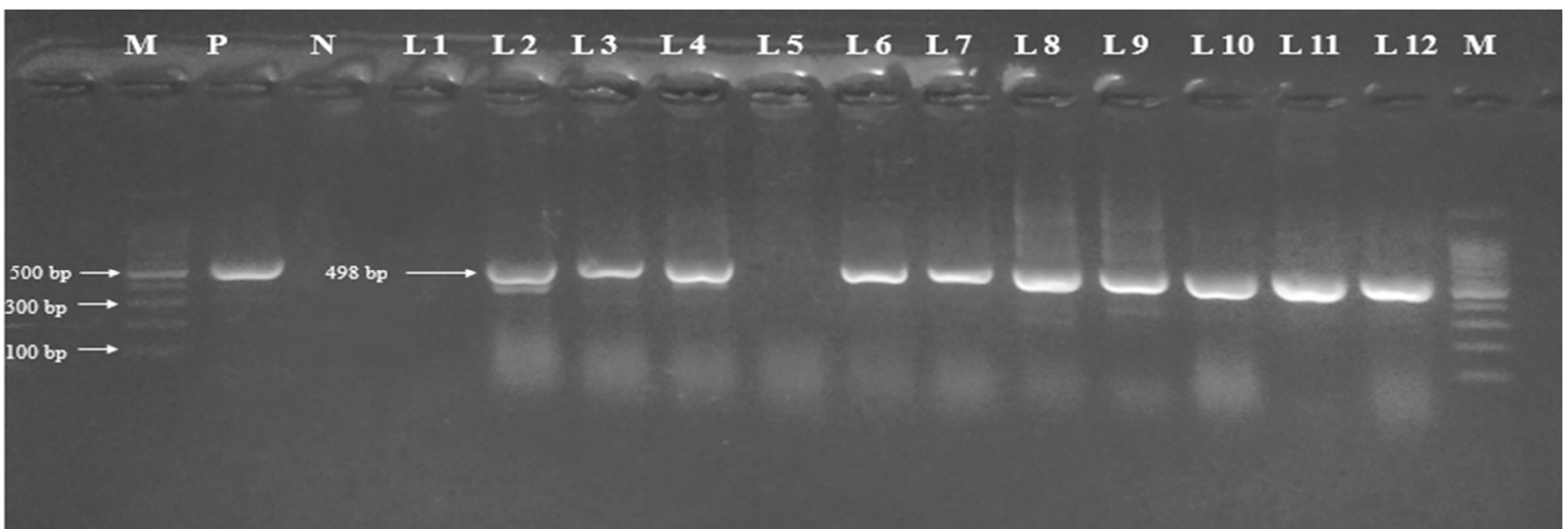

Figure 3. Electrophoretic pattern of PCR products 498 bp on 1.5\% agarose gel stained with Ethidium bromide. Lane $M$ is standard DNA marker, Lane $P$ is positive control, Lane $N$ is negative control, Lane2,3,4,6,7,8,9,10,11,12 is positive PCR products of $B$. abortus 498 bp and Lane 1 and 5 is negative PCR products for $B$. abortus.

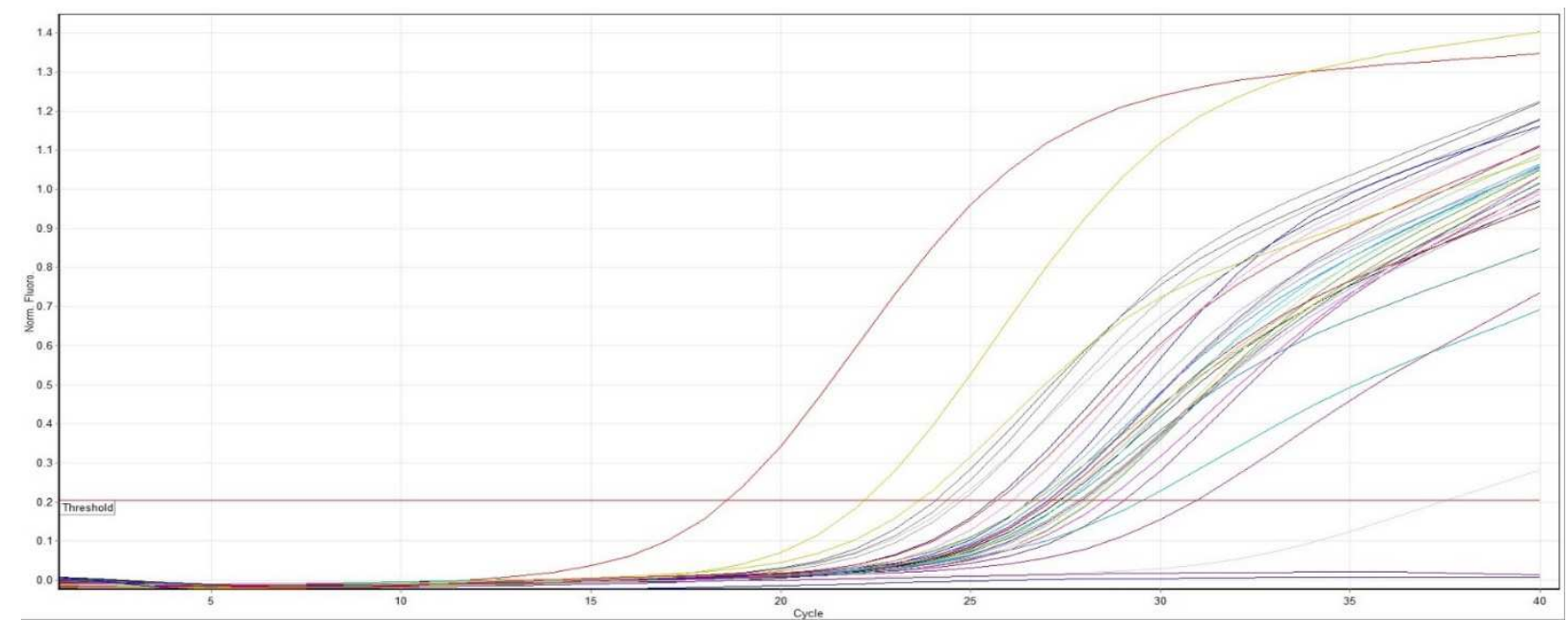

Figure 4. Overall real-time amplification results

\section{DISCUSSION}

The results of the first part of experiment presented in table 3 reflected that real-time PCR assay is more accurate, reliable and rapid test for detection and differentiation of $B$. abortus and B. melitensis in serum samples of small and large ruminants as compared to conventional PCR. While the second part of experiment mentioned in table 4 the serum sample was found to be the preferred specimen for the diagnosis of brucellosis as compared to blood samples. Isolation and bacterial culture is still considered as gold standard tests for the diagnosis of brucellosis but are cumbersome and hazardous procedures (Wareth et al., 2014). The rapid, more sensitive and safe method of diagnosis is based on molecular tests and their application are increasing during recent years (Akhtar et al., 2010). Molecular assays can detect both live and dead bacteria even in highly 
contaminated samples as compared to culture method which cannot detect dead and contaminated samples (Saminathan et al., 2016). In the present study, we compared the two molecular techniques. We compared the real-time PCR assay with conventional PCRs and found out that real-time assay is more sensitive than conventional type of PCR assay. Previously, real-time has also been used as more sensitive technique for the diagnosis of brucellosis in Pakistan (Ali et al., 2015). In Egypt, real-time PCR has also been proved to more and better technique for diagnosis from milk samples for brucellosis (Wareth et al., 2014). Sola et al. (2014) also proved the real-time PCR assay to be more efficient for the detection of Brucella from the visceral organs of slaughtered animals. The present research work is also in agreement with studies of Sidor et al. (2013) who proved multiplex real time PCR to be more sensitivity as compared to conventional assays, and also used this technique for the detection of Brucella species from the blood, tissue and faecal specimens of marine mammals. Dehkordi et al. (2012) compared the TaqMan probe realtime PCR assay with single-step conventional PCR assay for the diagnosis of brucellosis. In this study, both the $B$. melitensis and $B$. abortus were detected from the abomasal contents of aborted fetuses of goats, sheep, cattle, buffalo and camel. The sensitivity and specificity of real-time PCR assay were proved to be $100 \%$ in comparison to single step conventional PCR. This higher sensitivity is because of elimination of post PCR amplification steps in real-time PCR assay, while conventional assay requires to run the amplified products on Gel (Redkar et al., 2001).In real-time PCR reaction amplification can be visualized through computerized generated software consisting of log and lag phase. Even cycle threshold can been seen through computer software. But in conventional PCR we can confirm the reaction after completion of cycles of amplification. There could be error during amplification reaction. Even after successful amplification there could be error during post PCR steps. Post PCR steps include Gel preparation, Ethidium bromide inclusion, Gel Electrophoresis and visualization through UV illuminator which are time consuming and labour intensive (Yang et al., 2007). So real-time PCR assay can also be used for large number of reactions but conventional PCR could be for less number of samples (Dehkordi et al., 2012).

In second part of experiment, we compared the clinical specimens of blood and serum for diagnosis of brucellosis. We found that the serum was more suitable specimen as compared to blood for diagnosis of Brucella infection. We observed more cases in serum to be positive as compared to blood. Previously, assay sensitivity for serum samples was found $94 \%$ as compared to $61 \%$ of blood samples (Zerva et al., 2001). While we also detected B. abortus in $90 \%$ serum samples as compare to $65 \%$ of blood samples in cattle. It can be concluded that, real-time PCR assay is more reliable and sensitive method for diagnosis of brucellosis. It can also be concluded that serum is the preferred and optimal clinical specimen for the diagnosis of brucellosis by realtime PCR assay.

Acknowledgments: The research project was funded by European Union funded project of PLCIP/PITCO and Higher Education Commission of Pakistan (PIN No. 21353245-2AV2-034).

\section{REFERENCES}

Akhtar, R., Z. I. Chaudhry, A. Shakoori, M. Ahmad, and A. Aslam (2010). Comparative efficacy of conventional diagnostic methods and evaluation of polymerase chain reaction for the diagnosis of bovine brucellosis. Vet. World. 3 (2): 53-56.

Ali, S., S. Akhter, H. Neubauer, F. Melzer, I. Khan, Q. Ali, and M. Irfan (2015). Serological, cultural, and molecular evidence of Brucella infection in small ruminants in Pakistan. J. Infect. Dev. Ctries. 9 (5): 470-475.

Ahmed, R., K. Muhammad, M. Rabbani, M. S. Khan (2017). Spatial Distribution of Soil Borne Brucella Species Specific DNA in Punjab, Pakistan. Pakistan J. Zool. 49 (5): 1739-1748.

Bricker, B.J., and S.M. Halling (1994). Differentiation of Brucella abortus bv. 1, 2, and 4, Brucella melitensis, Brucella ovis, and Brucella suis bv. 1 by PCR. J. clin. microbiol. 32 (11): 2660-2666.

Cvetnic. Z., J. Toncic, S. Spicic, M. Lojkic, S. Terzic, L. Jemersic, A. Humski, S. Curic, M. Mitak, and B. Habrun (2004). Brucellosis in wild boar (Sus scrofa) in the Republic of Croatia. Vet. Med. 49 (4): 115-122.

Dehkordi, F.S., S. Saberian, and H. Momtaz (2012). Detection and Segregation of Brucella abortus and Brucella melitensis in Aborted Bovine, Ovine, Caprine, Buffaloes and Camelid Fetuses by Application of Conventional and Real-time Polymerase Chain Reaction. Thai. J. Vet. Med. 42 (1): 13-20.

Foster, J.T., R.T. Okinaka, R. Svensson, K. D.B.K. Shaw, R.A. Robison, W.S. Probert, L.J. Kenefic, W.D. Brown, and P. Keim (2008). Real-time PCR assays of single-nucleotide polymorphisms defining the major Brucella clades. J. Cin. Microbiol. 46 (1): 296-301.

Habtamu, T.T., R. Rathore, K. Dhama and K. Karthik (2013). Isolation and molecular detection of Brucella melitensis from disease outbreak in sheep and Brucella abortus from cattle farm by IS711 and OMP2a gene based PCR. Int. J. Curr. Res. 5(07): 1920-1925. 
Karthik, K., R. Rathore, P. Thomas, A. Elamurugan, Arun T.R and K. Dhama (2014a). Serological and molecular detection of Brucella abortus from cattle by RBPT, STAT and PCR, and sample suitability of whole blood for PCR. Asian. J. Anim. Vet. Adv. 9(4): 262-236 269.

Karthik, K., R. Rathore, P. Thomas, T.R. Arun, K.N. Viswas, R.K. Agarwal, H.V. Manjunathachar and K. Dhama (2014b). Loop mediated isothermal amplification test for specific and rapid detection of Brucella abortus in cattle. Vet. Quarterly. 34(4):174-9.

Karthik, K., R. Rathore, P. Thomas, K.N. Viswas, R.K. Agarwal, V. Rekha, R.V. Jagapur and K. Dhama (2016). Rapid and visual loop mediated isothermal amplifi cation (LAMP) test for the detection of Brucella spp. and its applicability in epidemiology of bovine brucellosis. Veterinarski Arhiv. 86 (1): 35-47.

Khan, M.Z and M. Zahoor (2018). An Overview of Brucellosis in Cattle and Humans, and its Serological and Molecular Diagnosis in Control Strategies. Trop. Med. Infect. Dis. 3(2): 65. Doi: 10.3390/tropicalmed3020065.

Navarro, E., M.A. Casao, and J. Solera (2004). Diagnosis of human brucellosis using PCR. Expert Review of Molecular diagnostics. 4 (1): 115-123.

Nielsen, K., P. Smith, J. Widdison, D. Gall, L. Kelly,W. Kelly, and P. Nicoletti (2004). Serological relationship between cattle exposed to Brucella abortus, Yersinia enterocolitica O: 9 and Escherichia coli O157: H7. Vet. Microbiol. 100 (1-2): 25-30.

Pappas, G., P. Papadimitriou, N. Akritidis, L. Christou, and E.V. Tsianos (2006). The new global map of human brucellosis. Lancet. Infect. Dis. 6 (2): 9199.

Probert, W.S., K.N. Schrader, N.Y. Khuong, S.L. Bystrom, and M.H. Graves (2004). Real-time multiplex PCR assay for detection of Brucella spp., B. abortus, and B. melitensis. J. Clin. Microbiol. 42 (3): 1290-1293.

Redkar, R., S. Rose, B. Bricker, and V. DelVecchio (2001). Real-time detection of Brucella abortus,Brucella melitensis and Brucella suis. Mol. Cell. Probes. 15 (1): 43-52.
Scott, J.C., M.S. Koylass, M.R. Stubberfield, and A.M. Whatmore (2007). Multiplex assay based on single-nucleotide polymorphisms for rapid identification of Brucella isolates at the species level. Appl. Environ. Microbiol. 73 (22): 7331 7337.

Sidor, I.F., J.L. Dunn, G.J. Tsongalis, J. Carlson, and S.J. Frasca (2013). A multiplex real-time polymerase chain reaction assay with two internal controls for the detection of Brucella species in tissues, blood, and feces from marine mammals. J Vet. Diagn. Invest. 25 (1): 72-81.

Sola, M.C., E.A. da Veiga Jardim, M.R. de Freitas andn of Brucella spp. DNA in lesions and viscera of bovine carcasses. J. Microbiol. Methods. 104 (1): 87-91.

Saminathan M, R. Rana, M.A. Ramakrishnan, K. Karthik, Y.S. Malik, and K. Dhama (2016). Prevalence, Diagnosis, Management and Control of Important Diseases of Ruminants with Special Reference to Indian Scenario. J. Exp. Biol. Agri Sci. 4(3): 338-367.

Verma, A.K., K. Dhama, S. Chakraborty, A. Kumar, R. Tiwari, A. Rahal and S.V. Singh (2014). Strategies for combating and eradicating important infectious diseases of animals with particular reference to India: present and future perspectives. Asian. J. Anim. Vet. Adv. 9(2): 77-106.

Wareth, G., F. Melzer, M.C. Elschner, H., Neubauer, and U. Roesler (2014). Detection of Brucella melitensis in bovine milk and milk products from apparently healthy animals in Egypt by real-time PCR. J. Infect. Dev. Ctries. 8 (10): 1339-1343.

Yang, S.J., H.S. Shim, J.T. Woo, H.S. Kim, and S.S. Lee (2007). Bacteriological detection of Brucella abortus and its characterization by PCR in the sporadic outbreak of bovine brucellosis in Gyeonggi province. Korean. Society. Poul. Sci. 30 (2): 251-258

Zerva, L., K. Bourantas, S. Mitka, A. Kansouzidou, and N. Legakis (2001). Serum is the preferred clinical specimen for diagnosis of human brucellosis by PCR. J. Clin. Microbiol. 39 (4): 1661-1664. 